\title{
LETTERS
}

\section{The end of forceps deliveries?}

I read with much concern the article by Muraca and colleagues on the outcome of operative deliveries. ${ }^{1}$

Although I applaud the immense amount of work this paper entailed, it was the conclusion at the end of the paper that midforceps deliveries were associated with more complications and cesarean section was safer in this setting that I question.

These findings have been published in many other studies; however, this is a very complicated situation, and other variables not in these studies (e.g., expertise; type of forceps; position of baby confirmed by two operators; and size and anatomy of the pelvis, bony and soft tissue) are never mentioned. These limit all studies.

There is no such thing as a standard pelvis or standard patient, and randomization would be impossible in the tense setting of a midforceps delivery.

This article will be quoted for years ahead. Even though I have used forceps for nearly 50 years. I have, in my own practice, reduced many of the quoted complications, by careful selection of the patient, forceps and type of pelvis. Cesarean section is not a simple option in many cases and is also associated with complications.

It would be unfortunate if this article brings forceps use to the end, just like the article by Hannah and colleagues on breech delivery brought the vaginal breech delivery to an end. ${ }^{2}$ No one will have any skills, experience and confidence to deliver a baby this way. It is going to be "fall out or chop the baby out."

\section{Nicholas Pairaudeau MB BS}

Consultant Obstetrician and Gynecologist, University of Toronto, Toronto, Ont.

Cite as: CMAJ 2017 August 28;189:E1097. doi: $10.1503 /$ cmaj. 733247

\section{References}

1. Muraca GM, Skoll A, Lisonkova S, et al. Perinatal and maternal morbidity and mortality after attempted operative vaginal delivery at midpelvic station. CMAJ 2017;189:E764-72.

2. Hannah ME, Hannah WJ, Hewson SA, et al.; Term Breech Trial Collaborative. Planned caesarean section versus planned vaginal birth for breech presentation at term: a randomised multicentre trial. Lancet 2000;356:1375-83.

Competing interests: None declared. 